\title{
O DIREITO DE TER PROPRIEDADE
}

\author{
Luciane Martins Carneiro de Sousa ${ }^{1}$
}

\section{RESUMO}

Neste trabalho será mostrada a importância da propriedade para os homens. Sendo assim, serão analisadas as teorias que justificam o vínculo da propriedade com o homem e que liame tão forte é este capaz de excluir qualquer outro da propriedade já ocupada.

Palavras-chave: Propriedade. Teorias da propriedade.

\section{THE RIGTH OF HAVING PROPERTY}

\begin{abstract}
In this work it will be shown the importance of property for the men. For this purpose, the theories which ground the link between the property and the man and the consequence of excluding anyone of the occupied property will be analysed.

Key-Words: Property. Theories of property.

\section{INTRODUÇÃO}

Ao longo dos anos a propriedade se mostrou tão importante para o indivíduo, como se fosse sagrado, algo intrinsecamente ligado a ele, algo que faz parte do homem, sendo extensão de sua personalidade e reflexo de seu ser interior.

A propriedade significa para o homem sua liberdade, o homem através dela existe como idéia, faz representar o espírito livre do mesmo. Para o indivíduo ela é tão importante que é considerada por ele como a exteriorização de seu ser pensante, sua alma, seu caráter, chega a ser a expressão da idéia que cada qual tem de si, podendo nela expressar sua personalidade.

\footnotetext{
${ }^{1}$ Possui Graduação em Direito pela Faculdade de Direito de Anápolis (1996) e é Especialista em Direito Civil Constitucional pela Universidade do Estado do Rio de Janeiro - UERJ (2009). Atualmente é Professora Tutora Direito Civil, atuando principalmente nos seguintes temas: responsabilidade civil, posse e propriedade..
} Auxiliar da Universidade do Estado do Rio de Janeiro - UERJ. Tem experiência na área de Direito, com ênfase em
\end{abstract}


Pela importância dada à mesma é que vamos analisar as teorias que justificam o vínculo da propriedade com o homem, e que liame tão forte é este capaz de excluir qualquer outro da propriedade já ocupada.

Alguns filósofos acreditam que a propriedade é um direito natural, preexistente à sociedade e o que a legitima é o trabalho.

A teoria do trabalho utiliza o argumento de que cada um tem a propriedade da sua pessoa e que o trabalho é obra das suas mãos. Quando o homem tira a coisa do estado que a encontra e incorpora seu trabalho a tal coisa, insere nela o que lhe pertence. Assim, adquire a propriedade daquilo que incorpora.

Esse trabalho estabelece uma distinção entre esses bens e os bens comuns, ao acrescentar a ele valor seu, a coisa passa a ser de sua propriedade, embora antes a coisa ser direito de todos, agora passa a ser de quem empreendeu seu trabalho.

A vontade é usada também para justificar este laço intelectual que liga o homem a propriedade, essa relação, por ato de minha vontade. Esta vontade tem direito ao respeito sempre que se exerce legitimamente. Basta que eu declare meu o objeto para que a apropriação, por si só, seja válida de direito e, não apenas de fato.

Vamos também ver a posição do pensamento em relação à propriedade de alguns filósofos como Locke, Rousseau, Grotius, Emile Durkhein, Hegel e outros.

Por fim, analisaremos a função social da propriedade, pensamento moderno que faz com que o homem justifique sua posse e propriedade em relação à coisa possuída.

\section{VALOR DA PROPRIEDADE}

De onde vem o respeito inspirado pela propriedade alheia, uma coisa tão estreitamente ligada à pessoa que chega a participar da inviolabilidade desta.

O que faz com que o homem tenha a noção de propriedade alheia a ponto de respeitá-la? O respeito não vem somente porque esta expresso nas leis, cada indivíduo sabe que algo pertence a alguém, tem a exata noção de que aquilo não lhe pertence, até mesmo as crianças têm em si a noção de propriedade, como se fosse uma noção preexistente. E quando foi que se chegou a tal ponto de proteção desse direito? A propriedade é para o indivíduo algo tão importante que parece estar ligada diretamente a ele.

Primeiramente, deve ser analisado em que consiste o liame a unir assim à pessoa, objetos a ela exteriores, os quais, naturalmente, não fazem parte dela própria. 
Como pode o homem dispor de certo bem, com a exclusão de qualquer outro, sobre os direitos em relação a tal bem. É a legitimidade dessa exclusão que torna ilegítimo a usurpação de qualquer outro. A solução mais simples seria considerar esse liame como decorrente da existência natural do homem. ${ }^{2}$

A propriedade significa para o sujeito dar um domínio exterior para a sua liberdade a fim de existir como idéia, pois a pessoa é a vontade infinita em si e para si, tal coisa distinta dela, que pode constituir o domínio da sua liberdade, determina-se como o que é imediatamente diferente e separável. ${ }^{3}$

A propriedade é distinta do espírito livre do homem, mas, a faz representar, o espírito livre tem conhecimentos próprios, saber, talentos que se são interiores e não exteriores, mas pode dar-lhes uma existência exterior mediante a expressão e assim aliená-los. Passam eles assim a categoria de coisas. Não aparecem, pois, de repente como imediatos, mas vêm a sê-lo por intermédio do espírito que passa para a imediateidade e a extrinsecidade o que é intrínseco. ${ }^{4}$

Para o indivíduo a propriedade é considerada como a exteriorização de seu ser pensante, sua alma, seu caráter, atribuem à propriedade a independência de seu íntimo, é nela que o homem exterioriza suas idéias, pensamentos, constitui para ele a verdade da realidade interna. Por isso, a propriedade é tão importante para o ser humano, pois, faz parte de seu ser, é expressão do íntimo que cada qual vê em si, a ligação de ambos é espiritual. $\mathrm{O}$ eu se apodera de alguma coisa para a satisfação das suas exigências dos seus desejos e do seu livre-arbítrio.

É aquele aspecto pelo qual eu, como vontade livre, me torno objetivo para mim mesmo na posse e, portanto, pela primeira vez, real, é esse aspecto que constitui o que há naquilo de verídico e jurídico, a definição da propriedade. A propriedade para o homem aparece como um meio e a liberdade tem na propriedade a sua primeira existência. É a minha vontade pessoal, individual, que se torna objetiva para mim na propriedade; esta adquire por isso o caráter de propriedade privada, e a propriedade comum, que segundo a sua natureza pode ser ocupada individualmente, define-se como

\footnotetext{
${ }^{2}$ Durkheim, Emile. Lições de sociologia, a moral, o direito e o Estado. Editora da Universidade de São Paulo. São Paulo, 1983, p. 108

${ }^{3}$ Hegel, George Wilhelm Friedrich. Princípios da filosofia do direito. Martins Fontes. São Paulo, 1997, p.45

${ }^{4}$ Hegel, George Wilhelm Friedrich. Op. cit, p.45
} 
uma comunidade virtualmente dissolúvel e na qual só por um ato do meu livre-arbítrio eu cedo a minha parte. ${ }^{5}$

\section{TEORIA DA PROPRIEDADE}

A propriedade mais se sente do que se define. Não é apenas o homem do direito que visualiza a propriedade, a criança, os mais rudes de espírito também têm a noção inata, defendem a relação jurídica dominial, resistem ao desapossamento, combatem o ladrão. Todos "sentem" o fenômeno propriedade. ${ }^{6}$

É difícil explicar a propriedade, pois em tempos remotos a terra produzia frutos naturalmente e sustentava animais que não pertenciam a ninguém pois eram originários da natureza, pertenciam então à humanidade.

Dentre as teorias utilizadas para se descobrir porque o homem é e deve ser proprietário a teoria do trabalho pareceu ser lógica.

A teoria do trabalho utiliza o argumento de que cada um tem a propriedade da sua pessoa e que o trabalho é obra das suas mãos. Portanto o homem incorpora seu trabalho a qualquer coisa que venha a tirar do estado em que a natureza a criou e insere nela o que lhe pertence, assim, adquire a propriedade daquilo que incorpora. Esse trabalho estabelece uma distinção entre esses bens e os bens comuns, ao acrescentar a ele seu trabalho a coisa passou a ser de sua propriedade, embora antes a coisa ser direito de todos, agora passa a ser de quem empreendeu seu trabalho.

O trabalho do homem é a pessoa em ação, gastando sua energia natural em algum tipo de atividade, é a manifestação da faculdade intelectual ou motora. Não cabe indagar de onde vem o fato de elas serem ligadas ao sujeito, pois deles provêm, deles fazem parte. Ele as possui como se possui a si mesmo. Haveria continuidade perfeita entre um e outro, e um não passaria de aspecto particular do outro. A propriedade diz Stuart Mill, nada implica além do direito de cada qual a seus talentos pessoais, ao que pode produzir, aplicando-os. ${ }^{7}$

A teoria do trabalho conclui que se empregamos a força contida em nós para execução de alguma atividade, ou seja, se executamos o trabalho dispondo da livre

\footnotetext{
${ }^{5}$ Hegel, Georg Wilhelm Friedrich. Op. cit. p.51

${ }^{6}$ Pereira, Caio Mario da Silva. Instituições de Direito Civil. Forense. Rio de Janeiro, $12^{\circ}$ edição, 1995, volume IV. P. 70

${ }^{7}$ Durkheim, Emile. Op. cit. p. 110
} 
disposição das energias e dos talentos implicados neste trabalho devemos também ter a livre disposição dos produtos do mesmo.

Mas, embora os homens tivessem direito a apropriar-se, cada qual com seu trabalho da terra, tanto quanto podiam, isso nunca deveria ser em excesso, nem causar prejuízo aos outros, uma vez que, a terra pertencia originariamente a toda humanidade, não pode o homem apossar de parte de outra pessoa e não dar a ela uma destinação.

Pois, se poderemos dispor com tamanha liberdade de nossas faculdades, devemo-nos a outrem, aos grupos diversos dos quais fazemos parte. Nós lhes damos, e temos a obrigação de dar-lhes, o melhor de nós mesmos. O culto da pessoa não exclui, de modo nenhum, a possibilidade de semelhante obrigação. Pois, a pessoa à qual esse culto é devido é a pessoa em geral. ${ }^{8}$

Quem se apropria da terra com seu trabalho não diminui, mas aumenta as provisões comuns da humanidade: com efeito, os bens adequados ao sustento da vida humana, produzidos por um acre de terra delimitada e cultivada, são, no mínimo, dez vezes mais do que aqueles fornecidos pelo mesmo acre de terra igualmente rica, mas deixada inculta e em comum. ${ }^{9}$

Antes da apropriação da terra, aquele que colhesse quantos frutos silvestres conseguisse, aquele que matasse, capturasse e domesticasse quantos animais conseguisse, aquele que prodigalizasse seus esforços em algum produto espontâneo da natureza, dedicando a ele o seu trabalho, de tal modo a removê-lo do estado em que a natureza o havia colocado, adquiria com isso a sua propriedade. Mas, se esses bens se deteriorassem em sua mão, sem que deles ele fizesse o devido uso, se os frutos ou a caça apodrecessem antes que ele pudesse servir-se deles, ele pecava contra a lei natural comum e era suscetível de punição: havia usurpado a parte do vizinho, pois só tinha algum direito àqueles bens por aquele tanto que seu uso requeresse e por aquilo que eles pudessem servir para assegurar seus meios de subsistência. ${ }^{10}$

É a propriedade do trabalho que cria em todas as coisas a diferença do valor.

Mas, a teoria do trabalho não leva em conta que a propriedade não é somente adquirida pelo trabalho, mas também pela troca, doações, herança, usucapião, etc. Isto contradiz o princípio segundo o qual a propriedade resulta do trabalho. O trabalho por si só não pode ser a causa geradora da propriedade. Quantidade muito desigual de trabalho

\footnotetext{
${ }^{8}$ Durkheim, Emile. Op. cit. p. 110

${ }^{9}$ Locke, John. Segundo tratado sobre o governo: ensaio relativo à verdadeira origem, extensão e objetivo do governo civil. São Paulo: Ed. Martin Claret, 2005. p. 47

${ }^{10}$ Locke, John. Op. cit, p. 45
} 
pode também dar origem a propriedades de valor igual. Isto é, num dos casos o trabalho foi substituído por outro valor que não o trabalho. Muitas vezes também o valor da propriedade depende da opinião da sociedade, requisito fora do valor trabalho desenvolvido pelo homem. ${ }^{11}$

A posse de um bem não é determinada somente pela constituição natural desses objetos, mas também, pela opinião da sociedade, é ela quem determina quais objetos são suscetíveis de apropriação e por qual valor.

Durkheim insistiu na idéia de que o valor é matéria de opinião. É a opinião de cada sociedade que faz sejam tais objetos considerados como suscetíveis de apropriação, e tais outros não. Assim entra realmente algo além do trabalho do proprietário, ainda quando o objeto possuído haja saído, efetivamente, de suas mãos; entra além de contribuição vinda da matéria, elemento vindo da sociedade, conforme gostos ou necessidades sociais, nossa propriedade cresce ou decresce, em nossas mãos, embora nenhuma influência tenhamos nessas variações. ${ }^{12}$

Filósofos se debruçaram sobre o tema para tentar explicar a importância da propriedade para o homem, a ligação entre ele e o que o leva a ter direto de ter propriedade.

Alguns acreditam que a propriedade é um direito natural, tendo por consequiência o homem direito a tal, outros afirmam que a propriedade somente surgiu com o advento do estado civil.

Hobbes por exemplo, assevera em sua obra o leviatã, que a propriedade só surge com o advento do estado civil, pois, no estado de natureza não haveria qualquer regramento para disciplinar as relações entre os indivíduos. Portanto, não seria possível delimitar o que pertenceria a cada um e muito menos conferir proteção a cada propriedade, afinal não existiria um soberano dotado de legitimidade para intervir na esfera individual. Hobbes também defendia que somente o direito à vida era inalienável e não a propriedade. ${ }^{13}$

Já para Locke a propriedade já existia no estado de natureza, sendo um direito natural do indivíduo, o qual não pode ser violado pelo Estado. $\mathrm{O}$ homem é naturalmente livre e proprietário de sua pessoa e de seu trabalho, e como a terra fora dada por Deus, em comum a todos os homens, quando o homem incorpora seu trabalho à matéria bruta

\footnotetext{
${ }^{11}$ Durkheim, Emile. Op. cit. p. 114

${ }^{12}$ Durkheim, Emile. Op. cit. p. 114

${ }^{13}$ Hobbes, Thomas. Leviatã ou matéria, forma e poder de um estado eclesiástico e civil. Martin Claret. São Paulo. 2004. pág. 184
} 
que se encontra em estado natural, o homem torna sua a propriedade e passa a ter domínio privado. Para Locke o trabalho é o fundamento originário da propriedade. ${ }^{14}$

$\mathrm{Na}$ formulação de Locke, a propriedade é um direito natural e inalienável, servindo de fundamento para a criação do governo civil e para a atribuição de direitos políticos aos indivíduos, verifica-se uma separação entre os homens que tem e os que não tem propriedade, de modo que somente são dotados de cidadania os proprietários de bens e posses. Em resumo, para Locke, o maior e principal objetivo de os homens se reunirem em sociedade, aceitando um governo comum é para preservação da propriedade.

O estado de natureza para Locke era relativamente estável, mas, quando havia a violação da propriedade, tais como vida e liberdade, os indivíduos entravam em estado de guerra uns com os outros. Essa necessidade de paz fez com que os indivíduos se unissem e estabelecesse livremente entre si o contrato social, que simbolizava a passagem do estado de natureza para a sociedade política ou civil. Seu objetivo era a preservação da propriedade e a proteção da comunidade tanto dos perigos internos quanto externos.

O contrato social de Locke é diferente do contrato de Hobbes, para este os homens firmavam um pacto de submissão pelo qual visavam a preservação de suas vidas, transferem a um terceiro, homem ou assembléia, a força coercitiva da comunidade, trocando voluntariamente a liberdade pela segurança do Estado leviatã.

Para Locke o contrato social é um consentimento em que os homens concordam livremente em formar a sociedade civil para preservar e consolidar ainda mais os direitos que possuíam originalmente em estado de natureza. ${ }^{15}$

Para Locke o fundamento da propriedade individual deve ser procurado no trabalho, empregado para apropriar-se de uma coisa ou para transformá-la, valorizandoa economicamente. Assim, ele assume como pilar da sua construção teórica a teoria do valor-trabalho, especialmente quando assevera que é o trabalho que provoca a diferença de valor nas coisas que nos rodeiam. ${ }^{16}$

\footnotetext{
${ }^{14}$ Locke, John. Segundo tratado sobre o governo: ensaio relativo à verdadeira origem, extensão e objetivo do governo civil. Op., cit 37

${ }^{15}$ Locke, John. Segundo tratado sobre o governo: ensaio relativo à verdadeira origem, extensão e objetivo do governo civil. Op., cit. p. 40.

${ }^{16}$ Locke, John. Segundo tratado sobre o governo: ensaio relativo à verdadeira origem, extensão e objetivo do governo civil.Op., cit. p. 45-50.
} 
Tratando da aquisição da propriedade, Locke considera que o trabalho é uma propriedade inalienável e serve como instrumento para se obter a propriedade privada. Como Deus deu a terra para todos, haveria uma igualdade no direito à terra; sendo a propriedade um direito natural, pré-existente ao Estado.

Buscando estabelecer os fundamentos da propriedade, Locke viu-se diante de duas doutrinas, a de Hobbes, que concebia a propriedade como direito positivo, e a de Pufendorf, que a incluía na categoria do direito natural convencional, categoria entre o direito natural e o direito positivo, que consistia num produto da sociedade natural fundado na vontade. "O momento da emergência da propriedade estava entre o estado natural e o estado civil: era o momento do direito convencional, nascido de acordos recíprocos". ${ }^{17}$

Nas páginas do Primeiro Tratado sobre o Governo, Locke demonstra que a doação do mundo, contida no Gênesis I, 28-29, foi realizada em benefício de toda a humanidade. A descrição da propriedade originária supõe a sua definição como um direito em comum que pertence a todos os membros da espécie humana. Quando afirmou que, o que quer que Deus tenha outorgado através das palavras dessa concessão não o outorgou para Adão em particular, à exclusão de todos os demais homens, qualquer que tenha sido o domínio que lhe outorgou mediante tal concessão, não se tratava de um domínio privado, mas um domínio em comum com o restante da humanidade, Locke destruiu a imagem de que o mundo pertencia ao domínio privado de Adão e seus herdeiros, ele a substituiu por outra igualitária que mostrava a propriedade como pertencente a ninguém, mas disponível a apropriação de todos. ${ }^{18}$

Para a teoria da propriedade de Locke, deve-se permitir que os outros tenham recursos para sobreviver, o homem pode conquistar a propriedade da terra com o emprego do seu trabalho, porém apenas na medida do que conseguir, produzir e consumir, a exploração da propriedade deveria se dar através do trabalho, porém não

\footnotetext{
${ }^{17}$ Sahd, Luiz Felipe Netto de Andrade e Silva, considerações sobre o fundamento moral da propriedade. Kriterion: Revista de Filosofia, Belo Horizonte, ${ }^{\circ}$ 115, 2007. Disponível em http://www.scielo.br/scielo.php?pid=S0100-512X2007000100013\&script=sci_arttext\&tlng=en, p.5, consulta em 16/03/2011.

${ }^{18}$ Locke, John. Segundo tratado sobre o governo: ensaio relativo à verdadeira origem, extensão e objetivo do governo civil. Op., cit. p. 37.
} 
estabelecia se o trabalho deveria ser próprio ou se compreenderia ainda o de outrem em favor do proprietário. ${ }^{19}$

Locke também fala da moeda, que estabelece um valor intrínseco à terra. Assim, a terra passa a valer per si, independentemente do trabalho nela empregado, Nesse sentido passa a prevalecer a teoria do valor, segundo a qual o trabalho produz valor e o atribui às coisas. De acordo com a teoria objetiva do valor, uma coisa tem a sua importância estipulada pela quantidade de trabalho gasto para produzi-la. Já para a teoria subjetiva do valor, uma coisa deve ser estimada pelo interesse que desperta nas pessoas. Com o surgimento da moeda, esta passou a servir como instrumento de troca do valor excedente produzido pelos proprietários, com o seu trabalho e o dos seus empregados, que então passaram a justificar o seu monopólio de terras através do não perecimento da produção. ${ }^{20}$

Hugo Grotius fundamentou a propriedade a partir do que já havia sustentado em 1609 no Mare liberum. Para Grotius, as coisas do mundo haviam sido entregues aos homens em um regime de comunhão indivisível dos bens. Um regime que deixava aberto o conteúdo do mundo ao uso de toda a humanidade, uma vez que por natureza não havia nada que pudesse ser considerada uma propriedade privada. Essa situação supõe que no estado de natureza cada homem pode tomar à natureza o que desejar para o seu usufruto, fazendo assim, às vezes, um uso particular do direito de propriedade. Mediante a ocupação do necessário para sobreviver, o suum de cada homem se projeta sobre as coisas consumidas. É exatamente isso que Grotius pensa quando escreve sobre a regeneração do mundo após o dilúvio. Cada um podia se apropriar para suas necessidades do que quisesse e consumir o que podia ser consumido. $O$ uso desse direito universal tinha então a função de propriedade, pois, do que alguém se havia apropriado outro não podia tirá-lo dele sem injustiça. Uma primeira particularização do mundo teve lugar, pois as coisas consumidas pelos homens não admite nenhum outro uso posterior, transformando-se em substância do ocupante quando, utilizando-as, experimentaram um abuso que as fez degenerar irreversivelmente. ${ }^{21}$

Kant afirmava que se não virmos na propriedade senão a detenção material, será fácil destruí-la analiticamente. Juízo analítico, segundo Kant, é aquele em que o atributo

\footnotetext{
${ }^{19}$ Locke, John. Segundo tratado sobre o governo: ensaio relativo à verdadeira origem, extensão e objetivo do governo civil. Op., cit. p. 40.

${ }^{20}$ Locke, John. Segundo tratado sobre o governo: ensaio relativo à verdadeira origem, extensão e objetivo do governo civil. Op., cit. p. 45.

${ }^{21}$ GROCIO, H. De la libertad de los mares. Tradución de V. de Blanco e L. García Arias. Madrid: Centro de Estúdios Constitucionales, 1979. p. 68/70/87
} 
está necessariamente compreendido no sujeito, este é a priori, a este juízo se opõe o juízo sintético, aquele em que o atributo acrescenta algo à compreensão do sujeito, este é a posteriori. ${ }^{22}$

A ligação do homem com a propriedade o laço que os une só pode ser intelectual, como a coisa permanece independente de minha pessoa, onde quer que eu resida, cumpre, essa dependência, de algum estado mental situado, ele próprio, de algum modo fora do espaço. Quando digo possuir um campo, embora situado em lugar de todo diverso daquele no qual me encontro realmente, não se trata senão de relação intelectual entre mim e o objeto. Essa relação está fundada em ato de minha vontade. Só com efeito minha vontade está liberta de toda condição espacial, as legislações por elas prescritas são válidas e obrigatórias para os homem, seja qual for sua situação local. ${ }^{23}$

Este laço intelectual que liga o homem a propriedade, essa relação, esta fundada em ato de minha vontade. Esta vontade tem direito ao respeito sempre que se exerce legitimamente. Basta que minha vontade se haja legitimamente determinado a declarar seu esse objeto para que a apropriação, por si só, seja válida de direito e, não, apenas de fato. A minha vontade é respeitada, sagrada para outrem sempre que empregada sem violação da regra do direito, que só ele, poderia criar liame intelectual entre essas coisas e minha pessoa. Quando minha vontade se firmou conforme o direito, deve ser respeitada. O caráter sagrado da vontade conforme a lei da conduta. ${ }^{24}$

Quando declaro cada qual obrigado a abster-se do objeto sobre o qual assim versa minha vontade, essa pretensão supõe nos reconheçamos reciprocamente, obrigados, diante de cada qual, a abster-nos, igualmente, do seu exterior de cada qual. Não tenho obrigação de respeitar o que cada qual declara seu, se cada qual não me assegurar, por sua parte, que se conduzirá com referência a mim, segundo o mesmo princípio. Como minha vontade é individual não pode dar lei aos outros. Semelhante obrigação só pode ser estabelecida por uma vontade coletiva superior a cada vontade individual tomada em separado. Não posso obrigar a todos de se absterem de violar a minha vontade, pois, ela não passa de vontade individual, não posso fazê-lo senão em nome da vontade coletiva de todos quantos possuem essa coisa em comum. ${ }^{25}$

Assim, se chega a seguinte conclusão, as coisas são originalmente possuídas por uma coletividade natural, formada por toda humanidade, e o direito de apropriação

\footnotetext{
${ }^{22}$ Durkheim, Emile. Op. cit, p. 109

${ }^{23}$ Durkheim, Emile. Op. cit, p. 115

${ }^{24}$ Durkheim, Emile. Op. cit, p. 116

${ }^{25}$ Durkheim, Emile. Op. cit. p. 117
} 
implica comunidade originária das coisas e dela deriva, o único proprietário legítimo é originariamente a humanidade. E a humanidade pode exercer este direito de duas maneiras, ou declarar ser tudo dela e nada de ninguém, ou pode reconhecer a cada qual o direito de apropriar-se de tudo quanto possa, ressalvados os direitos concorrentes de outrem. Não posso apropriar-se de uma coisa senão com a condição de não avançar no direito similar de outrem, será necessário e suficiente minha apropriação anterior à de outrem. Uma vez declarada minha vontade, nenhuma outra pode declarar-se em sentido contrário; mas, inversamente, se nenhuma outra vontade se declarou a minha pode afirmar-se com toda a liberdade. E como é pela ocupação que se afirma a vontade de apropriação, a condição da legitimidade de minha apropriação é ser o primeiro ocupante. Posso ser proprietário tão longe quanto possa defendê-la quem dela queira apropriar-se. Não se pode avançar no direito de outros, condição preenchida desde que o solo apropriado ainda não ser ocupado. ${ }^{26}$

Toda apropriação é legítima quando feita em solo assim apropriado; e a vontade que preside a essa apropriação tem direito ao respeito desde que se declarou, ainda quando o sujeito e a coisa não estejam em contato.

No entanto, a teoria não leva em consideração conflitos que possam surgir em razão de vontades sobre o mesmo objeto, $\mathrm{O}$ ponto fraco está em estabelecer que a anterioridade da ocupação basta a fundar, juridicamente e moralmente, que as vontades não se negam mutuamente, que as vontades não avançam umas nas outras, por não se encontrarem materialmente no mesmo objeto.

Para Kant a teoria da ocupação da propriedade se resume da seguinte maneira. $\mathrm{O}$ globo é propriedade do gênero humano. Deve ser apropriada individualmente ou por pequenos grupos, porções restritas de terra, por outro lado, como a vontade, quando suas decisões são legítimas, tem direito ao respeito, toda primeira ocupação é respeitável, e a consciência do gênero humano deve reconhecer-lhe a legitimidade. $\mathrm{O}$ direito legado a mim pela humanidade, isto é, em suma, por minha qualidade de homem, só pode ser limitado pelo direito similar dos outros homens. Se, pois, os outros homens não afirmaram seu direito a propósito de coisas das quais me aproprio, meu direito sobre elas é absoluto. E como os decretos de minha vontade tiram seu valor de minha própria vontade, e esta se situa fora do espaço, o ato pelo qual me declaro proprietário de uma coisa me faz proprietário dessa coisa, ainda quando não a detenha

\footnotetext{
${ }^{26}$ Durkheim, Emile. Op. cit. p. 118
} 
materialmente. Encontramos nessa doutrina a teoria moral do direito do primeiro ocupante. $^{27}$

No entanto, se a vontade é tudo quanto podem ser independentemente de suas manifestações espaciais, podem entrar em conflito sem choque material. Ou seja, se me aproprio de um objeto ainda não de fato apropriado por outrem, mas querido por esse outrem, sem expressão física desta vontade, não haverá usurpação? A teoria responde que não há objetos não suscetíveis de ser queridos por outros que não aquele que deles efetivamente toma posse. Precisamente por ser ato mental o ato de querer, também o próprio equilíbrio das vontades individuais deve ser mental, isto é, moral. ${ }^{28}$

Rousseau reduzia o direito de propriedade ao direito de primeira ocupação consagrado e sancionado pela sociedade. Apenas limitava os direitos do ocupante por suas necessidades normais. Todo homem tem direito ao que lhe é necessário.

Rousseau afirmava que para autorizar sobre um terreno qualquer, o direito do primeiro ocupante, exigem-se as condições seguintes: o primeiro que esse terreno ainda não seja habitado por ninguém; segundo, que só ocupemos a quantidade necessária à subsistência. Acrescenta Rousseau ser a cultura e o trabalho necessários à verdadeira tomada de posse. É que o trabalho é o único sinal autêntico de ocupação. ${ }^{29}$

Rousseau subordina a extensão da ocupação legítima à extensão das necessidades normais. Diferente da teoria de Kant onde o direito do primeiro ocupante era ilimitado aqui é restrito. Rousseau era dominado pelo equilíbrio natural cujas condições dependem da natureza do homem.

\section{COMO SE DEU A PROPRIEDADE PARA ROUSSEAU}

O primeiro que, cercando um terreno, se lembrou de dizer: "Isto é meu" e encontrou pessoas bastante simples para o acreditar, foi o verdadeiro fundador da sociedade civil. Quantos crimes, guerras, assassinatos, misérias e horrores não teriam sido poupados ao gênero humano aquele que arrancando as estacas ou tapando o fosso, tivesse gritado a seus semelhantes: "Não escutem esse impostor! Vocês estarão perdidos se esquecerem que os frutos são de todos e que a terra não é de ninguém! ${ }^{30}$

\footnotetext{
${ }^{27}$ Durkheim, Emile. Op. cit., p. 121

${ }^{28}$ Durkheim, Emile. Op. cit., p. 121

${ }^{29}$ Rousseau, Jean-Jacques. Do contrato social. São Paulo: Ed. Martin Claret, 2004. P.36

${ }^{30}$ Rousseau, Jean-Jacques. A Origem da Desigualdade entre os Homens. Editora escala, São Paulo, p. 57
} 
RFD- Revista da Faculdade de Direito- UERJ, v. 2, n. 21, jan./jun. 2012

No entanto, a evolução do homem para chegar neste ponto deu-se paulatinamente, foi necessário mudanças no pensamento do mesmo antes de se chegar a esse termo.

Para explicar como se chegou até a propriedade e qual a importância desta, Rousseau relata como se deu a evolução do homem no estado de natureza.

O Primeiro sentimento do homem foi o de sua existência e seu primeiro cuidado foi o de sua conservação. O instinto o levou a fazer uso da terra, saciando a fome e experimentando diversas maneiras de existir. Depois advieram as dificuldades e foi necessário aprender a vencê-las, foi preciso ultrapassar os obstáculos e à medida que o gênero humano se estendia, as dificuldades se multiplicavam para os homens. Ao longo do mar e dos rios inventaram a linha e o anzol e se tornaram pescadores, e nas florestas, fizeram arcos e flechas e se tornaram caçadores e guerreiros. Desse desenvolvimento aumentaram a superioridade do homem sobre os outros animais. Foi assim que o primeiro olhar que lançou sobre si mesmo produziu nele o primeiro movimento de orgulho. Os homens deixaram de dormir em árvores ou de se retirar nas cavernas. $\mathrm{O}$ hábito de viver coletivamente fez surgir os mais doces sentimentos conhecidos dos homens, o amor conjugal e o amor paternal. Os homens, até então errantes nos bosques, tendo adquirido uma situação mais fixa aproxima-se lentamente, reúnem-se em diversos grupos e formam uma nação particular. Antes de terem sido inventados os sinais representativos das riquezas, essas só podiam consistir em terras e em animais, os únicos bens reais que os homens podem possuir. Quando as heranças foram crescendo em número e em extensão, a ponto de cobrirem o solo inteiro e se tocarem todas, umas não puderam mais crescer senão à custa de outras e os excedentes, que a fraqueza ou a indolência tinham impedido de adquiri-las por sua vez, tornados pobres sem ter perdido nada porque, tudo mudando em torno deles, só eles não tinham mudado, foram obrigados a receber ou a roubar a subsistência das mãos dos ricos. Os ricos, por seu lado, mal conheceram o prazer de dominar e passaram logo a desdenhar todos os outros e, servindo-se de seus antigos escravos para submeter novos, não pensaram senão em subjugar e escravizar os vizinhos, como lobos esfaimados. ${ }^{31}$

Assim foi para Rousseau a evolução do homem e a descoberta do valor da propriedade para o mesmo que com ela subjuga seu semelhante, fazendo valer seu status social, ganhando importância, favores, gloria e riquezas.

\footnotetext{
${ }^{31}$ Rousseau, Jean-Jacques, A Origem da Desigualdade entre os Homens. Op. cit, p. 57-70
} 
Enquanto Locke apresenta a propriedade como direito inalienável e objeto de proteção por parte do Estado, Rousseau a qualifica como a degeneração do homem e aproxima-se de Hobbes ao asseverar que ela somente surge com o advento do Estado.

Rousseau faz uma associação entre liberdade natural e posse e liberdade civil e propriedade, de maneira que fora do estado civil não há propriedade, mas apenas posse. Ele só admitia a existência de propriedade caso estivesse de acordo com a vontade geral do povo e se a terra estivesse desocupada, sua utilização deveria ser voltada para a subsistência e sua exploração deveria ser real e efetiva.

Diferentemente de Locke, para quem o Estado só poderia se intrometer em questões relativas à propriedade para protegê-la, Rousseau entende que, justamente pelo fato de que o Estado a criou, este pode limitá-la e organizá-la em nome da vontade geral e em conformidade com os interesses e as necessidades da coletividade.

\section{DO PACTO SOCIAL}

$\mathrm{Na}$ teoria do contrato social desenvolvida por Rousseau os indivíduos se associam e ocorre a total alienação de cada associado, com todos os seus direitos, em benefício da comunidade. Não sendo total essa alienação o indivíduo ficará exposto à dominação do outro. O cidadão obedece à vontade geral. Aceitando a autoridade da vontade geral o cidadão não só passa a pertencer a um corpo moral coletivo como adquire liberdade obedecendo a uma lei que prescreve para si mesmo.

Como os homens não podem criar novas forças além da natural, unem-se para criar uma soma de forças capaz de resistir e vencer a resistência, é uma sociedade que defende e protege com toda a força comum a pessoa e os bens de cada sócio, pela qual, unindo-se cada um obedecem a si mesmos.

Quando o contrato social fala do primeiro ocupante afirma que o Estado a respeito é senhor de todos seus bens pelo contrato social, que o Estado serve de fundamento a todos os direitos, mas não o é a respeito das outras potências, senão pelo direito de primeiro ocupante, que alcançou dos particulares.

O direito do primeiro ocupante ainda que mais real que o do mais forte, somente se converte em verdadeiro direito depois de estabelecido o de propriedade. Todo o homem tem naturalmente direito a tudo que lhe é necessário; mas o ato que o torna proprietário de algum bem exclui o bem de todo o resto, e não tem mais direito à comunidade. 
Geralmente para autorizar o direito de primeiro ocupante em qualquer terreno, são necessárias as seguintes condições: primeiro que ninguém habite ainda esse terreno; em segundo lugar, que se ocupe só a quantidade necessária à subsistência; em terceiro, que se tome posse dele, não por uma vã cerimônia, mas pelo trabalho e cultura, únicos sinais de propriedade que, em falta de títulos jurídicos, os outros devem respeitar. ${ }^{32}$

\section{PODERES ORIGINÁRIOS DA PROPRIEDADE}

Para tentar justificar a relação do possuidor com a coisa possuída tenta-se buscar os poderes do possuidor em relação a ele, objeto possuído. As faculdades inerentes ao direito de propriedade podem ser conceituadas como o poder concedido pelo ordenamento jurídico à pessoa para a satisfação de interesses próprios.

O código de Napoleão ensaiou uma definição dos poderes de propriedade, o direito de gozar e dispor das coisas de maneira mais absoluta, desde que delas não se faça uso proibido pelas leis e regulamentos. ${ }^{33}$

O direito de usar, ius utendi, é a faculdade do proprietário de servir-se da coisa de acordo com sua destinação econômica, consiste na faculdade de colocar a coisa a serviço do titular, sem modificação na sua substância. Usar não é somente extrair efeito benéfico, mas também ter a coisa em condições de servir. Modernamente o direito positivo cada vez mais restringe as prerrogativas dominiais, ora limitando a utilização, ora impondo-a em benefício da coletividade.

Direito de gozar, ius fruendi, realiza-se essencialmente com a percepção dos frutos, consiste na exploração econômica da coisa, mediante a extração de frutos e produtos.

Direito de dispor, ius abutendi, entende-se como a faculdade que tem o proprietário de alterar a própria substância da coisa. O direito romano empregava o verbo abutere para traduzir este atributo, traduzindo-o literalmente, a reconhecer no proprietário o poder extremo de abusar da coisa. Mas é certo que o direito romano não concedia tal prerrogativa, fazendo ao revés conter o domínio em termos compatíveis

\footnotetext{
${ }^{32}$ Rousseau, Jean-Jacques, Do contrato Social. Martin Claret. São Paulo, pág. 36

${ }^{33}$ Pereira, Caio Mario da Silva, Instituições de Direito Civil, Forense, Rio de Janeiro, 1995, $12^{\circ}$ edição, volume IV, p.71
} 
com a convivência social. Sendo a faculdade de transformar a coisa, seja consumindoa, seja de outra forma, ou aliená-la, de mudar-lhe a situação jurídica. ${ }^{34}$

Direito de reivindicar, também é denominado elemento externo ou jurídico da propriedade, por representar a pretensão do titular do direito subjetivo de excluir terceiros de indevida ingerência sobre a coisa, este direito permite que o proprietário permaneça no domínio do bem, de nada adiantaria os poderes de usar, gozar e dispor da coisa se não pudesse o proprietário reivindicá-la das mãos de quem injustamente a detenha.

\section{PROPRIEDADE E CARÁTER SAGRADO}

A idéia de propriedade desperta a idéia de uma coisa, mas o que pode ser apropriado é relativo no tempo, e muda conforme os costumes de determinada sociedade. Em nossa cultura escravos eram de seu senhor, indiscernível do direito de propriedade. Em Roma antiga o filho família, salvo concernente em suas relações públicas, era considerado como objeto de propriedade.

A noção de propriedade esta ligada a das coisas sagradas, as chamadas em Roma, res sacrae et religiosae, estavam fora do comércio, não era possuído por ninguém, dizia ser propriedade dos deuses. Há também as chamadas, em Roma, res communes, as que não pertencem a ninguém por pertencerem a todos. ${ }^{35}$

A coisa apropriada é separada do domínio comum, essa característica é também a de todas as coisas sagradas. O vulgo não pode fruir delas. Só podem usá-la aqueles portadores de um parentesco com essa espécie de coisa, sagrada como ela. Esses interditos é que estão na base da chamada instituição do tabu. Tabu é o pôr à parte um objeto como consagrado, como pertencente ao domínio divino. Em virtude disso, é interdita a apropriação, sob pena de sacrilégio, do objeto tabu, no qual, até, é proibido tocar. Só podem usá-la aqueles que também são tabu. O domínio habitado por um sacerdote, por um chefe, era tabu para o vulgo, não podia ser habitado pelo povo, essa mesma porção era propriedade do senhor. ${ }^{36}$

Esta noção em torno da coisa apropriada e da coisa sagrada mantém algo em comum, pois, de algum modo todos os indivíduos devem manter-se distantes, apartados

\footnotetext{
${ }^{34}$ Pereira, Caio Mario da Silva. Instituições de Direito Civi. Forense, Rio de Janeiro, 1995, $12^{\circ}$ edição, volume IV, p.74

${ }^{35}$ Durkheim, Emile. Op. cit, p. 125

${ }^{36}$ Durkheim, Emile. Op. cit, p. 130
} 
da coisa apropriada e da sagrada, somente podem tocá-la aqueles que têm qualidade necessária para tal.

Em certos casos, pode-se observar diretamente a filiação da noção de tabu, ou de sagrado à de propriedade. Em Taiti, por exemplo, os reis, os príncipes, os grandes, são todos seres sagrados. O caráter sagrado é contagioso e se comunica a quem toca o objeto investido desse caráter. Um chefe não pode entrar em contato com uma coisa sem que ela, por isso mesmo, venha a tornar-se tabu, no mesmo grau e da mesma maneira. Por isso, esses personagens não saem senão carregados aos ombros, de outra forma tocariam o solo e dele se apropriariam. Declarar tabu uma coisa, ou dela apropriar-se vem a ser sinônimos. Como se houvesse descoberto, ao pé de Honolulu, uma mina de diamantes, a rainha a declarou tabu, a fim de reservar-lhe a propriedade. Cedido um terreno a um estrangeiro, era declarado tabu para subtraí-lo aos indígenas. Durante a colheita, ou a pesca, o campo ou o rio eram declarados tabu a fim de proteger-lhes os produtos. ${ }^{37}$

A propriedade apresenta a mesma contagiosidade, pois o domínio compreendido pela primeira se estende à segunda. O proprietário da terra torna-se também dono dos frutos e dos produtos da coisa, ainda quando delas destacados. O artigo 1.232 do Código Civil declara que os frutos e mais produtos da coisa pertencem, ainda quando separados, ao seu proprietário, salvo se, por preceito jurídico especial, couberem a outro, podemos ver também tal dispositivo no aluvião, artigo 1250; avulsão, artigo 1251; e na construção e plantação, artigo 1254 e artigo 1255.

Assim, sempre vemos a proximidade de uma coisa sagrada e a propriedade. $\mathrm{O}$ respeito à propriedade, portanto, não provém do respeito imposto pela personalidade humana, seja individual, seja coletiva. Vem de fonte inteiramente outra, exterior à pessoa. Para saber de onde provém, cumpre indagar de como as coisas, ou os homens adquirem caráter sagrado. ${ }^{38}$

Esse direito é, pois, de origem religiosa, a propriedade humana não é senão a propriedade religiosa. O ver instituição tão fundamental, e tão geral, quanto a propriedade, repousar, assim, em crenças ilusórias e em preconceitos tidos como destituídos de fundamento objetivo. Mas, é que as religiões, ainda as mais grosseiras, não são como por vezes se acreditou simples fantasmagorias, sem nenhuma correspondência da realidade. Certo, não exprimem as coisas do mundo físico tais quais

\footnotetext{
${ }^{37}$ Durkheim, Emile. Op. cit, p. 131

${ }^{38}$ Durkheim, Emile. Op. cit., p. 144
} 
sejam. Mediante uma religião podemos reencontrar a estrutura de uma sociedade. As religiões são a maneira primitiva de as sociedades tomarem consciência de si mesmas, e de sua história. ${ }^{39}$

A apropriação particular supõe uma primeira apropriação coletiva. Os fiéis se substituíam ao direito dos deuses, diremos que os particulares se substituíram ao direito da coletividade. É deste que emana toda a religiosidade. Só a coletividade tem poder bastante a elevar impedir ataques particulares. E a propriedade particular nasceu pelo fato de o indivíduo ter feito voltar-se em seu proveito, para seu uso, esse respeito inspirado pela sociedade, essa dignidade superior que a reveste, por ela comunicada às coisas das quais é feito seu substituto material. Esse sacrilégio que o homem crê cometer para com os deuses, pelo só fato de rasgar e revolver o solo, ele o comete, realmente, para com a sociedade, pois é a sociedade a realidade oculta atrás dessas concepções mitológicas. ${ }^{40}$

Em atenas a filha epicérica, que fille epiclère , à falta de melhor. Quando um pai não tinha como descendente senão uma filha, ela é que herdava, mas era a condição jurídica dos bens recebidos por ela, assim, que a ela lhe fixava a própria condição jurídica. Como esses bens não deviam sair da família, precisamente por serem a alma da mesma, a herdeira era obrigada a desposar seu mais próximo parente masculino; se já era casada, devia desmanchar o casamento ou deixar a herança. A pessoa seguia a coisa. A moça mais era herdada que herdava. ${ }^{41}$

De onde vem essa individualidade da propriedade, onde cada qual fez para si uma propriedade particular. Essa individualidade não ocorreu sem ser acompanhada de outras mudanças na situação respectiva das coisas e das pessoas.

Foi com o advento do poder e, mais especialmente, do poder patriarcal que desenvolveu-se a individualidade patrimonial. Em Roma, no inicio somente o patriarca era o único a exercer o direito de propriedade, à medida que a individualidade dos filhos começaram a ser objeto de reconhecimento ainda antes da morte do pai, puderam eles tornar-se proprietários. ${ }^{42}$

A propriedade romana primitiva da época rural é uma manifestação do amplo poder doméstico que o paterfamilias tem sobre determinadas pessoas. O poder sobre as coisas era distinto do poder sobre as pessoas. A época romana antiga não valora os bens

\footnotetext{
${ }^{39}$ Durkheim, Emile. Op. cit., p. 146

${ }^{40}$ Durkheim, Emile. Op. cit., p. 148

${ }^{41}$ Durkheim, Emile. Op. cit., p. 150

${ }^{42}$ Durkheim, Emile. Op. cit., p. 151
} 
como essencialmente patrimoniais, mas segundo o valor coletivo que tinha para a família. $^{43}$

\section{FUNÇÃO SOCIAL DA PROPRIEDADE}

A expressão função social procede do latim functio, cujo significado é de cumprir algo ou desempenhar um dever ou uma atividade. ${ }^{44}$

Hoje o vínculo jurídico que liga o homem a propriedade é exercido através da função social. O pensamento da sociedade se desenvolveu a ponto de não mais concordar com a apropriação da propriedade imobiliária somente para fins de especulação imobiliária. As transformações acompanhadas pela sociedade fizeram com que o pensamento em relação à propriedade também mudasse.

Apesar de a propriedade conferir um domínio pleno, não se pode abusar deste poder em prejuízo da coletividade. A evolução social demonstrou a justificação de um interesse maior que o interesse privado, não pode a propriedade ceder aos caprichos de seu dono, diante de tanta miséria e necessidades no mundo. A propriedade não pode permanecer inculta à espera de valorização. A noção de solidariedade que antes restava esquecida floresce diante das privações do mundo. Um dia a rebelião vem à tona e torna-se direito, isto acontece mais cedo ou mais tarde, toda vez que poucos usurpam o direito de muitos e faz valer a lei do mais forte.

Os valores individuais não podem prosperar diante da opressão da massa, privada de bens mínimos existenciais e excluídos do direito a terra.

A sua limitação por interesse social compete, na época mais antiga, ao critério do censor, que vela pelos bons costumes. Os censores no direito romano intervieram em caso de alienação de propriedade fundiária indispensável, de exploração insuficiente e ainda, de gastos imprudentes e de luxos efeminados. A vigilância censória dos costumes diminui na República tardia. A legislação combate também o luxo. ${ }^{45}$

Algumas disposições da lei das XII Tábuas contêm limitações da propriedade no interesse público, como, por exemplo, as que dizem respeito às edificações e política sanitária, de caráter religioso e combate ao luxo. Leis que regulavam as proibições de enterro dentro da cidade e cremação próximo a edifícios. Na época do principado

\footnotetext{
${ }^{43}$ Kaser, Max. Direito Privado Romano. Edição fundação Calouste Gulbenkian. Lisboa,1999, p. 138

${ }^{44}$ Rosenvald, Nelson; Chaves de Faria, Cristiano. Direitos Reais. $3{ }^{a}$ edição, Lumen Júris, 2006, p.200

${ }^{45}$ Kaser, Max, Direito Privado Romano. Op. cit, p. 141
} 
RFD- Revista da Faculdade de Direito- UERJ, v. 2, n. 21, jan./jun. 2012

aumentaram a vigilância no que diz respeito a conservação de edifícios, aquedutos e margem de rios. ${ }^{46}$

Os romanos determinavam a retirada dos atuais donos da propriedade de terrenos incultos, e ordenavam que a propriedade fosse atribuída a quem pudesse fazer com que a mesma fosse produtiva e que pudesse assumir com os encargos financeiros. $\mathrm{O}$ imperador Zenão no fim do século $\mathrm{V}$, decreta um regulamento de construções minucioso e exaustivo. Determinados prédios estão vinculados a deveres de prestação de serviços, quem delas adquirir terras tem de assumir a função que lhe está ligada ou de as restituir ao alienante. ${ }^{47}$

Hoje para que o homem tenha direito à terra é necessário dar a ela uma função social, caso contrário poderá ser surpreendido por quem melhor direito natural dê a ela, aquele que, apesar de não dono, concede à terra a sua real destinação.

\section{CONCLUSÃO}

O presente trabalho apresentou algumas teorias desenvolvidas por filósofos para justificar a importância da propriedade para o homem e para a sociedade.

Foi apresentada em resumo a visão Emile Durkheim, Locke, a teoria desenvolvida por Rousseau no contrato social, Hobbes em leviatã, e a fundamentação de Hugo Grotius.

Foi desenvolvido um pouco mais a noção de propriedade segundo Rousseau e como esta se deu. No desenvolvimento do estado de natureza para o estado social, esta evolução ocorreu paulatinamente, e foi necessário mudanças no pensamento do homem.

Depois foi apresentada a teoria do contrato social de Rosseau, onde os indivíduos se associam e ocorre a total alienação de cada associado, com todos os seus direitos, em benefício da comunidade.

Faz-se uma breve consideração sobre o direito do primeiro ocupante e sobre os poderes originários da propriedade.

Vimos os poderes do proprietário em relação à coisa possuída.

Logo após é feito a comparação da propriedade com o bem sagrado.

\footnotetext{
${ }^{46}$ Kaser, Max, Direito Privado Romano. Op. cit, p. 141

${ }^{47}$ Kaser, Max, Direito Privado Romano. Op. cit, p. 142
} 
Por fim, tratamos da noção de função social dada à propriedade, noção que hoje justifica o direito de propriedade.

\section{REFERÊNCIAS}

Durkheim, Emile. Lições de sociologia, a moral, o direito e o Estado. Editora da Universidade de São Paulo, 1993.

Hegel, George Wilhelm Friedrich. Princípios da filosofia do direito. Martins Fontes, São Paulo, 1997.

Locke, John. Uma teoria do título válido, tratado sobre o governo. A idéia de justiça de Platão a Rawls. In: Sebastiano Maffettone e Salvatore Veca. (1 ${ }^{\circ}$ ed. Org). Martins Fontes, São Paulo, 2005.

Mello, Leonel Itaussu Almeida. “John Locke e o individualismo liberal”.In: Weffort, Francisco, Os Clássicos da Política. Editora ática, São Paulo, 2006.

Rousseau, Jean-Jacques. A Origem da Desigualdade entre os Homens. Editora escala, São Paulo.

Rousseau, Jean-Jacques. Do contrato Social. Martin Claret, São Paulo, 2005.

Kaser, Max. Direito Privado Romano. Edição fundação Calouste Gulbenkian, Lisboa.

Pereira, Caio Mario da Silva. Instituições de Direito Civil, Forense, $12^{\circ}$ edição, volume IV, 1995 .

Rosenvald, Nelson; Chaves de Faria, Cristiano. Direitos Reais. $3^{\text {a }}$ edição, Lumen Júris, 2006.

Sahd, Luiz Felipe Netto de Andrade e Silva. Considerações sobre o fundamento moral da propriedade. Kriterion: Revista de Filosofia, Belo Horizonte, n¹15, 2007. 
RFD- Revista da Faculdade de Direito- UERJ, v. 2, n. 21, jan./jun. 2012

Disponível em http://www.scielo.br/scielo.php?pid=S0100-

$\underline{512 X 2007000100013 \& \text { script }=\text { sci } \_ \text {arttext\&tlng=en }}$

Hobbes, Thomas. Leviatã ou matéria, forma e poder de um estado eclesiástico e civil. Martin Claret. São Paulo. 2004.

Locke, John. Segundo tratado sobre o governo: ensaio relativo à verdadeira origem, extensão e objetivo do governo civil. São Paulo: Ed. Martin Claret, 2005.

Locke, John. Segundo tratado sobre o governo: ensaio relativo à verdadeira origem, extensão e objetivo do governo civil. São Paulo: Ed. Martin Claret, 2005.

GROCIO, H. De la libertad de los mares. Tradución de V. de Blanco e L. García Arias. Madrid: Centro de Estúdios Constitucionales, 1979. p. 68/70/87 